well tolerated by patients and are the most effective agents to date. If their long term safety is confirmed in large studies they are likely to become first line agents in the management of hypercholesterolaemia. They also have a role in patients with combined increases of cholesterol and triglyceride concentrations. Additional data on their impact on coronary morbidity and mortality are necessary, however, before the widespread use of statins is contemplated.

\section{OTHER DRUGS}

Neither neomycin or thyroxine is now recommended. Derivatives of $\omega-3$ fatty acids may have some role in the treatment of hypertriglyceridaemia, but their long term efficacy and safety has not been proved and some concern exists about the LDL raising actions of these agents. Several other compounds that reduce sterol absorption from the intestine (sucrose polyester, sitosterol, and neomycin analogues) or that inhibit enzymes associated with cholesterol esterification (acyl-cholesterol acyl-transferase inhibitors) are still under investigation.

\section{COMBINED TREATMENT}

When a single agent does not produce an adequate reduction in cholesterol or does so only by inducing undesirable side effects, a combination of agents may be efficacious, rational, and well tolerated by patients. The choice is often dictated by synergistic mechanisms, and some examples are shown in table II.

\section{Conclusion}

Increasing numbers of highly efficacious and well tolerated lipid lowering drugs are becoming available. Though many studies have shown a reduction in the incidence of cardiovascular events in patients treated with lipid lowering agents, no study to date has shown a favourable effect on the overall death rate. Nevertheless, these drugs should be regarded as part of the armoury and must always be combined with dietary treatment. Attention to other risk factors including hypertension, smoking, and diabetes is also clearly indicated.

1 Kannel WB, Doyle JT, Ostfeld AM, et al. Atherosclerosis study group. Optimal resources for primary prevention of atherosclerotic diseases. Circulation 1984;70:155-205A.

2 Hulley SB, Rhoads CG. The plasma lipoproteins as risk factors: comparison of electrophoretic and ultracentrifugation results. Metabolism 1982;31:773-7.

3 Gordon T, Kannel WB, Castelli WB, Dawber TR. Lipoproteins, cardiovascular disease and death. The Framingham study. Arch Intern Med 1981;141:1128-31.

4 Goldbourt U, Holtzman E, Neufeld HN. Total and high density lipoprotein cholesterol in the serum and risk of mortality: evidence of a threshold effect. Br Med F 1985;290:1239-43.

5 Pocock SJ, Shaper AG, Phillips AN, Walker M, Whitehead TP. High density lipoprotein cholesterol is not a major risk factor for ischaemic heart disease in
lock lipoprotein cholesterol is not a major risk
British men. Br Med f 1986;292:515-9.

6 Peto R, Yusuf S, Collins R. Cholesterol lowering trial results in their epidemiological context. Circulation 1985;72:451. (Abstract No 1083.)

7 Duffield RGM, Lewis B, Miller NE, Jameson CW, Brunt JNH, Colchester ACF. Treatment of hyperlipidaemia retards progression of symptomatic femoral atherosclerosis. A randomised controlled trial. Lancet 1983;iii:63942.

8 Brensike JF, Levy RI, Kelsey SF, et al. Effects of therapy with cholestyramine on progression of coronary atherosclerosis: results of the NHLBI type II coronary intervention study. Circulation 1984;69:313-24.

9 Kane JP, Malloy MJ, Tun P, et al. Normalisation of low density lipoprotein levels in heterozygous familial hypercholesterolaemia with a combined drug regimen. $N$ Engl f Med 1981;304:251-8.

10 Ball MJ, Mann JI. Drug treatment for hypercholesterolaemia. $Q \mathcal{f}$ Med 1986;232:733-5.

11 The British Cardiac Society. Working Group on Coronary Prevention Conclusions and recommendations. Br Hearl $\mathcal{F}$ 1987;57:188-9.

12 Study Group, European Atherosclerosis Society. The recognition and management of hyperlipidaemia in adults: a policy statement of the European Atherosclerosis Society. Eur Heart f 1988;9:571-600.

13 National Cholesterol Education Program Expert Panel. Report on detection, cvaluation, and treatment of high blood cholesterol in adults. Arch Intern Med 1988;148:36-69

14 Brown MS, Goldstein JL. How LDL receptors influence cholesterol and atherosclerosis. Sci Am 1984;251:58-66.

15 Lipid research clinics program. The lipid research clinics coronary primary prevention trial results. I. Reduction in the incidence of coronary heart diseasc. FAMA 1984;251:351-64.
16 Lipid research clinics program. The lipid research clinics coronary prımary prevention trial. II. The relationship of reduction in incidence of coronary heart disease to cholesterol lowering. FAMA 1984;251:365-74.

17 Shepherd J, Packard CJ, Bicher S, Lawric TDV, Morgan G. Cholestyramine promotes receptor mediated low density lipoprotein catabolism. $N$ Engl $\mathcal{J}$ Med 1980;302:1219-22.

18 Schaefer EJ, Levy RI. Pathogenesis and management of lipoprotein disorders. N Engl f Med 1985;312:1300-10.

19 Kane JP, Malloy MJ. Treatment of hypercholesterolaemia. Med Clin North Am 1982;66:537-50.

20 The Coronary Drug Project Research Group. Findings leading to further modifications of its protocol with respect to dextrothyroxine. $\mathcal{J A M A}$ 1972;220:996-1008.

21 Committee of Principal Investigators. A cooperative trial in the primary prevention of ischaemic heart disease using clofibrate. Br Heart $\mathcal{F}$ 1978; 40:1069-118.

22 Committee of Principal Investigators. WHO cooperative trial on primary prevention of ischaemic heart disease using clofibrate to lower serum prevention of ischaemic heart disease using clofibrate

23 Havel R. Familial dysbetalipoproteinemia: new aspects of pathogenesis and diagnosis. Med Clin North Am 1982;66:441-54.

24 Shepherd J, Packard CJ. An overview of the effects of p-chlor-phenoxyisobutyric acid derivatives on lipoprotein metabolism. In: Fears R, ed. Pharmacological control of hyperlipidaemia. Barcelona, Spain: JR Prous, 1986:135-44.

25 Monk JP, Todd PA. Bezafibrate: a review. Drugs 1987;33:539-76.

26 Niort G, Bulgarelli A, Cassander M, Pagano G. Effect of short term treatment with bezafibrate on plasma fibrinogen, fibrinopeptide $\mathrm{A}$, platelet activation and blood filterability in atherosclerotic hyperfibrinogenemic patients. Atherosclerosis 1988;71:113-9

27 Kesaniemi YA, Grundy SM. Influence of gemfibrozil and clofibrate on metabolism of cholesterol and plasma triglycerides in man. FAMA 1984: 251:2241-7.

28 Frick $\mathrm{MH}$, Ello $\mathrm{O}$, Haapa $\mathrm{K}$, et al. Helsinki heart study: primary-prevention trial with gemfibrozil in middle aged men with diplipidemia. Safety of treatment, changes in risk factors and incidence of coronary heart disease. N Engl F Med 1987;317:1237-45.

29 Todd PA, Ward A. Gemfibrozil: a review of its pharmacodynamic and pharmacokinetic properties, and therapeutic use in dyslipidaemia. Drugs 1988;36:314-39.

30 Brown WV, Dujovne CA, Farquhar JW, et al. Effects of fenofibrate on plasma lipids. Arteriosclerosis 1986;6:670-8

31 Knopp RH, Brown WV, Dujovne CA, et al. Effects of fenofibrate on plasma lipoproteins in hypercholesterolaemia and combined hyperlipidaemia. $A m \mathcal{f}$ Med 1987;83 (suppl 5B):50-9.

32 Chapman MJ. Pharmacology of fenofibrate. Am J Med 1987;83 (suppl 5B): 21-5.

33 Blane GF. Comparative toxicity and safety profile of fenofibrate and other fibric acid derivatives. Am $\mathcal{F}$ Med 1987;83 (suppl 5B):26-36.

34 Rouffy J, Chancu B, Bakir R, Djian F, Goy-Leoper J. Comparative evaluation of the effects of ciprofibrate and fenofibrate on lipids, lipoproteins and apoproteins A \& B. Atherosclerosis 1985;54:273-81.

35 Illingworth DR, Olsen GD, Cook SF, Sexton GJ, Wendel HA, Connor WE. Ciprofibrate in the therapy of type II hypercholesterolaemia - a double blind trial. Atherosclerosis 1982;44:211-21,

36 Olsson AG, Oro L. Dose-response study of the effect of ciprofibrate on serum lipoprotein concentrations in hyperlipoproteinaemia. Atherosclerosis 1982; 42:229-43.

37 Stirling C, McAleer M, Reckless JPD, et al. Effects of acipimox, a nicotinic acid derivative, on lipolysis in human adipose tissue and on cholesterol synthesis in human jejunal mucosae. Clin Sci 1985;68:83-8.

38 Crepaldi G, Avogaro P, Descovich GC, et al. Plasma lipid lowering activity of acipimox in patients with type II and type IV hyperlipoproteinemia: results of a multicenter trial. Atherosclerosis 1988;70:115-21.

39 Canner PL, Berge KG, Wenger NK, et al. Fifteen year mortality in coronary drug project patients: long term benefit with niacin. $\mathcal{f} \mathrm{Am}$ Coll Cardiol drug project patien
$1986 ; 8: 1245-55$.

40 Baker SG, Joffe Bi, Mendelsohn D, Seftel HC. Treatment of homozygous familial hypercholesterolaemia with probucol. S Afr Med f 1982;62:7-11.

41 Yamamoto A, Matsuzawa Y, Yokoyama S, Funahashi T, Yamamura T, Kishino B. Effects of probucol on xanthoma regression in familial hypercholesterolaemia. Am f Cardiol 1986;57:29H 35H

42 Steinberg D. Studies on the mechanism of action of probucol. Am $\mathcal{F}$ Cardiol 1986;57:16H-21H

43 Grundy SM. HMG-CoA reductase inhibitors for treatment of hypercholesterolemia. $N$ Engl f M Med 1988;319:24-33.

44 Tobert JA. New developments in lipid lowering therapy: the role of inhibition of hydroxy methylglutaryl-coenzyme A reductase. Circulation 1987;76: $534-8$.

\section{Correction}

\section{ABC of Transfusion}

Testing before transfusion, and blood ordering policies

An error occurred in this paper by Dr Marcela Contreras and Professor P L Mollison (9 December, p 1448). A sentence was omitted from the eighth line of the second paragraph, which should read ". . . be incubated at $37^{\circ} \mathrm{C}$ for $30-60 \mathrm{~min}$ (10 min in low ionic strength solution), washed thoroughly...."

\section{Transfusion of red cells}

An error occurred in the legend to a pair of photographs in this paper by Drs Sally C Davies and Milica Brozović (27 January, $\mathrm{p} 249$ ). The photograph on the right hand side of the pair depicts microcytic red cells and not macrocytic red cells as printed. 